Стовба Тетяна Анатоліївна кандидат економічних наук, доцент кафедри економіки та морського права, Херсонська державна морська академія, м. Херсон, 73000, пр. Ушакова, 20, тел.: (0552) 49-59-02, e-mail: stovba.t1210@gmail.com, https://orcid.org/0000-0003-2433-1122

\title{
СТРАТЕГІЧНІ ІМПЕРАТИВИ ІННОВАЦІЙНОГО РОЗВИТКУ МОРСЬКИХ ПОРТІВ УКРАЇНИ
}

Анотація. Морські порти України мають значний потенціал для розвитку транспортних шляхів і вантажопотоку, але не спроможні забезпечити збільшення обсягів вантажообігу через велику кількість проблем. Інноваційний розвиток сприятиме виходу з скрутного стану портової галузі.

Інноваційний розвиток організації означає процес кількісних $\mathrm{i}$ якісних перетворень, що спирається на перманентний пошук і впровадження нових способів і сфер реалізації потенціалу підприємства 3 метою набуття конкурентних переваг в умовах глобалізації економіки, спрямованих на задоволення потреб клієнтів, споживачів, партнерів підприємства, галузі, регіону, країни та одержання позитивного (економічного, соціального, екологічного, науково-технічного або іншого) ефекту.

Наразі головним імперативом інноваційного розвитку у світі $є$ цифровізація. Поширенню цифровізації у морських портах сприятимуть Інтернет речей, автоматизація, роботизація, безпілотні транспортні засоби та обладнання, розробки у галузі кібербезпеки, 3D-моделювання, 3D-друк, нанотехнології. Впровадження вищезазначених інновацій дозволить крім традиційної обробки суден оптимізувати рух та обслуговування суден i вантажів, прискорити i автоматизувати процеси завдяки більшій прозорості, зменшувати корупцію та кількість помилок i, таким чином, підвищувати ефективність функціонування морських портів.

Інвестиції у днопоглиблювальні роботи, сучасне потужне підйомнотранспортне обладнання, розширення акваторії порту для заходу та обробки великих суден, штучний інтелект та блокчейн для удосконалення обміну інформацією між різними учасниками процесу транспортування, створення сайтів для портових логістичних та виробничих операцій у портовій зоні дозволить збільшити трафік та кількість заходів суден, розробка і впровадження сучасних засобів для бункерування, а також використання скрапленого 
природного газу в якості суднового палива, електрифікація сприятимуть зменшенню шкідливих викидів у порту та підвищенню ефективності його роботи.

Ключові слова: морський порт, інновації, розвиток, інноваційний розвиток, інтелектуальний порт.

Stovba Tetyana Anatoliyivna Candidate of Economic Sciences, associate professor of Economics and Maritime Law Department, Kherson State Maritime Academy, Ushakov Ave., 20, Kherson, 73000, tel.: (0552) 49-59-02 e-mail: stovba.t1210@gmail.com, https://orcid.org/0000-0003-2433-1122

\section{STRATEGIC IMPERATIVES OF INNOVATIVE DEVELOPMENT OF UKRAINE SEA PORTS}

Abstract. Ukraine's seaports have significant potential for the development of transport routes and cargo flow, but can't to increase cargo turnover due to a large number of problems. Innovative development will help to overcome the difficult situation of the port industry.

Innovative development of the organization is the process of quantitative and qualitative transformation, based on the permanent search and implementation of new ways and areas of realization of enterprise potential in order to gain competitive advantage in a globalized economy to meet the needs of customers, consumers, partners, industry, region, country and obtaining a positive (economic, social, environmental, scientific, technical or other) effect.

Currently, the main imperative of innovative development in the world is digitalization. The Internet of Things, automation, robotics, unmanned vehicles and equipment, developments in the field of cybersecurity, 3D modeling and 3D printing, and nanotechnology will contribute to the spread of digitalization in seaports. The implementation of the above innovations will help in addition to traditional ship handling to help optimize the movement and maintenance of ships and cargo, speed up and automate processes through greater transparency, reduce corruption and errors and thus increase the efficiency of seaports.

Investments in dredging works, modern powerful lifting and transport equipment, expansion of port waters for handling of large vessels, artificial intelligence and blockchain to improve information exchange between different participants in the transportation process, creation of sites for port logistics and production operations in the port area will increase traffic and the number of ship measures, the development and implementation of modern bunkering facilities, as well as the use of liquefied natural gas as marine fuel, electrification will help reduce harmful emissions at the port and increase its efficiency. 
Keywords: seaport, innovative development, innovation, development, intellectual port.

Постановка проблеми. Морська портова галузь України охоплює 18 портів, 38 державних підприємств 3 оборотом приблизно 10 млрд. грн. на рік, 5000 галузевих суб'єктів господарювання [1]. У світі працюють біля 200 тис. моряківукраїнців [2]. Морські порти виконують важливу соціальну роль: одне робоче місце у портовій галузі сприяє створенню 4-5 робочих місць у суміжних галузях [1].

Морські порти $\epsilon$ складовою частиною транспортної i виробничої інфраструктури України. Портова галузь України має значний потенціал для розвитку транспортних шляхів i вантажопотоку 3 урахуванням світової кон'юнктури ринку, вигідне розташування на перетині міжнародних транспортних коридорів (ТРАСЕКА, «Новий шовковий шлях», Пан'європейські №3, №5, №7 та №9 тощо) для забезпечення транзитних вантажопотоків, але не спроможна збільшити обсяги вантажообігу і, відповідно, наповнити держбюджет, через велику кількість проблем.

Намагання іноземними судновласниками здійснювати євроазійські економічні зв'язки в обхід території України вимагає від Уряду України негайно модернізувати транспортну інфраструктуру 3 метою залучення транзитних вантажопотоків. Конкурентоспроможність транспортного комплексу на світовому ринку залежить від рівня оснащення та функціонування морських портів, відповідності їх системи управління та розвитку інфраструктури міжнародним вимогам.

Більшість розвинутих країн пов'язують сталість темпів економічного розвитку із постійним оновленням виробництва на інноваційних засадах, кардинальною зміною його структури. Це дозволило їм посісти провідні позиції в економічній сфері, здійснити прорив в окремих галузях, завоювати світові ринки та забезпечити благополуччя своїх громадян.

Тому Україні важливо запозичити досвід розвинених країн для досягнення економічного зростання, ефективно використовуючи власний наявний потенціал. Адже із зростанням пов'язане майбутнє України: економічна незалежність, міжнародна конкурентоспроможність, політичний авторитет, умови інтегрування до світової економіки та ін. Застосування такого підходу до зростання економіки України потребує узагальнення та подальшого розвитку теоретичних i практичних положень, що пов'язані із впровадженням інновацій для подальшого розвитку морських портів. А це питання є важливим, бо можливо вибрати хибний вектор розвитку та через 5 років позбутися усіх конкурентних переваг.

Метою статті $\epsilon$ аналіз дефініції «інноваційний розвиток», обгрунтування його ролі у функціонуванні портової галузі, а також визначення стратегічних 
напрямків розвитку вітчизняних морських портів на інноваційних засадах в умовах глобалізації економіки.

Виклад основного матеріалу. Розглядаючи інноваційний розвиток, необхідно звернути увагу на дві його складові: безпосередньо розвиток та сутність інновацій.

Почнемо з тлумачення дефініції «розвиток». Не існує єдиного підходу щодо визначення цього терміну (таблиця 1).

Таким чином, про розвиток можна говорити у разі, коли внаслідок поліпшення бізнес-процесів або управління ними, досягнуто якісний або кількісний приріст корисного результату процесу порівняно із колишнім рівнем або рівнем, досягнутим на інших виробництвах.

Таблиия 1

\section{Визначення категорії «розвиток» у працях вчених}

\begin{tabular}{|c|c|}
\hline Автори & Визначення \\
\hline $\begin{array}{l}\text { С.В. Мочерний } \\
\text { та ін. [3, с. 283] }\end{array}$ & $\begin{array}{l}\text { Розвиток економіки - це «закономірний процес кількісно-якісних змін у } \\
\text { межах економічної системи, їі перехід у нову якість, досконалішу форму. } \\
\text { Кількісним виміром цих процесів є відносна зміна макроекономічних } \\
\text { показників у напрямі зростання протягом відносно тривалого періоду, } \\
\text { наприклад кількох років» }\end{array}$ \\
\hline $\begin{array}{l}\text { А.С. Булатов та } \\
\text { iн. }[4, \text { с. } 354]\end{array}$ & $\begin{array}{l}\text { «Економічний розвиток є багатофакторним процесом, що відображає як } \\
\text { еволюцію господарського механізму, так і зміну на цій основі } \\
\text { економічних систем. Сам розвиток відбувається нерівномірно, має } \\
\text { періоди зростання та спаду, кількісні й якісні зміни в економіці, } \\
\text { позитивні, негативні тенденціі. Мабуть, економічний розвиток повинен } \\
\text { розглядатися за періоди часу» }\end{array}$ \\
\hline $\begin{array}{l}\text { Ф. Гуійяр та } \\
\text { Д. Келлі }[5, \text { с. 9] }\end{array}$ & $\begin{array}{l}\text { Сутність організаційного розвитку } \\
\text { фолягає }\end{array}$ \\
\hline $\begin{array}{l}\text { Н.В. Афанасьєв } \\
\text { та ін. [6]. }\end{array}$ & $\begin{array}{l}\text { Під розвитком пропонується розуміти об'єктивну зміну тільки якісних } \\
\text { характеристик системи, обумовлену як фундаментальними законами } \\
\text { природи (єдності і боротьби протилежностей, переходу кількості в якість } \\
\text { тощо), так і закономірностями функціонування конкретних систем } \\
\text { (старіння устаткування, нагромадження досвіду і знань співробітниками, } \\
\text { виснаження природних ресурсів) }\end{array}$ \\
\hline $\begin{array}{l}\text { О.І. Понома- } \\
\text { ренко } \\
\text { В.О. Поно- } \\
\text { маренко } \\
\text { [7, с.37] }\end{array}$ & $\begin{array}{l}\text { Розвиток економічної системи пов'язаний, в першу чергу, з умінням } \\
\text { використовувати наявні ресурси. Автори відзначають, що нині розвиток } \\
\text { переважно залежить від інформаційних, ніж від матеріальних ресурсів. } \\
\text { Розвиток підприємства є наслідком зростання прагнення і здатності } \\
\text { задовольняти як власні, так і чужі виправдані потреби й бажання. Під } \\
\text { виправданими потребами автори розуміють все те, що необхідно для } \\
\text { виживання. Виправданими бажаннями вони вважають ті, задоволення } \\
\text { яких не відбивається негативно на розвитку інших }\end{array}$ \\
\hline
\end{tabular}




\begin{tabular}{|l|l|}
\hline \multicolumn{1}{|c|}{ Автори } & \multicolumn{3}{|c|}{ Визначення } \\
\hline Н.В. Краснокут- \\
ська $[8$, с.46]. & Розглядає еволюційний та біфуркаційний напрями розвитку. \\
& Еволюційний шлях розвитку грунтується на кількісному накопиченні \\
& засобів виробництва і матеріальних ресурсів, що постійно \\
& вдосконалюються протягом існування технологічного укладу і базуються \\
& на використанні відомих науково-технічних досягнень. Біфуркаційний \\
& шлях - це революційний тип розвитку, що відбувається миттєво шляхом \\
& переходу до якісно нового стану і характеризується нестійкістю, \\
& нестабільністю, технологічними проривами, винаходами, науковими \\
& відкриттями, які функціонують за новими принципами \\
\hline
\end{tabular}

Перейдемо до розгляду трактування визначення «інновація». Визначення $\mathrm{i}$ сутність поняття «інновація» доповнюється певними аспектами, що враховують особливості певного етапу розвитку економіки. Розглянемо основні 3 них (таблиця 2).

Таблиия 2

\section{Визначення категорії «інновація» у працях вчених}

\begin{tabular}{|c|c|}
\hline Автори & Визначення \\
\hline $\begin{array}{l}\text { Л.Л. Антонюк, } \\
\text { А.М. Поручник, } \\
\text { В.С. Савчук }[9, \text { с.14] }\end{array}$ & $\begin{array}{l}\text { Виділяють вузький та широкий підходи до визначення інновацій. У } \\
\text { вузькому розумінні інновація уособлюється із новою технікою, } \\
\text { технологією, промисловим виробництвом. У широкому значенні } \\
\text { інновації розглядають як рентабельне використання ідей у вигляді } \\
\text { нових товарів, послуг, організаційно-технічних та соціально- } \\
\text { економічних рішень виробничого, фінансового, комерційного } \\
\text { характеру }\end{array}$ \\
\hline М. Портер [10, с.171]. & $\begin{array}{l}\text { Інновації виявляються у новому дизайні продукту, у новому } \\
\text { маркетинговому підході, в новій методиці підвищення кваліфікації } \\
\text { персоналу, вони можуть бути досить простими і невеликим, } \\
\text { базуючись найчастіше на нагромадженні незначних поліпшень і } \\
\text { досягнень, ніж на єдиному технологічному прориві }\end{array}$ \\
\hline $\begin{array}{l}\text { Й. Шумпетер } \\
{[11, \text { с. } 84-154]}\end{array}$ & $\begin{array}{l}\text { Сутність інновації полягає у рекомбінації концептуальних фізичних } \\
\text { матеріалів, які існували на ринку; вчений розглядає іiі як нову } \\
\text { комбінацію виробничих чинників. }\end{array}$ \\
\hline $\begin{array}{l}\text { Clive Crumball } \\
{[12, \text { c. } 57]}\end{array}$ & $\begin{array}{l}\text { Під інноваціями розуміє сукупність технічних, виробничих i } \\
\text { комерційних заходів, які сприяють виходу на ринок нових } \\
\text { поліпшених продуктів, у тому числі комерційне використання нових і } \\
\text { поліпшених процесів і обладнання }\end{array}$ \\
\hline $\begin{array}{l}\text { Ю. Яковець } \\
{[13, \text { с. } 95]}\end{array}$ & $\begin{array}{l}\text { Інновації - це якісні зміни у виробництві, які можуть стосуватись як } \\
\text { техніки та технології, так і форм організації виробництва та } \\
\text { менеджменту }\end{array}$ \\
\hline $\begin{array}{l}\text { Б. Твісс } \\
{[14, \text { с.37]. }}\end{array}$ & $\begin{array}{l}\text { Нововведення - це процес, завдяки якому винахід або ідея набувають } \\
\text { економічного змісту; це пропозиція на ринку чогось нового, за що } \\
\text { споживач готовий заплатити }\end{array}$ \\
\hline
\end{tabular}




\begin{tabular}{|l|l|}
\hline \multicolumn{1}{|c|}{ Автори } & \multicolumn{1}{|c|}{ Визначення } \\
\hline $\begin{array}{l}\text { Б.Санто } \\
{[15, \text { с.81] }}\end{array}$ & $\begin{array}{l}\text { Інновація - це суспільний, технічний або економічний процес, що } \\
\text { завдяки практичному використанню ідей та винаходів призводить до } \\
\text { створення кращих за своїми властивостями виробів, технологій, що } \\
\text { може принести додатковий дохід на ринку }\end{array}$ \\
\hline $\begin{array}{l}\text { О. Лапко } \\
{[16, \text { с.28] }}\end{array}$ & $\begin{array}{l}\text { Під інноваціями розуміє комплексний процес, який складається із } \\
\text { створення, розробки, доведення до комерційного використання і } \\
\text { розповсюдження нового технічного або іншого рішення, що } \\
\text { задовольняє певну потребу }\end{array}$ \\
\hline Х. Рігс $[17$, с.7] & Трактує інновацію як комерційне втілення нової ідеї \\
\hline В. Хіпель $[18$, с.19] & $\begin{array}{l}\text { Розуміє під інновацією застосування нового продукту або процесу у } \\
\text { практичній діяльності }\end{array}$ \\
\hline
\end{tabular}

Підсумовуючи, слід зазначити, що вчені характеризують інновації залежно від об'єкта та предмета власного конкретного дослідження.

У Законі України «Про інноваційну діяльність» введено наступне тлумачення терміна «інновація»: інновації - новостворені (застосовані) і (або) вдосконалені конкурентоспроможні технології, продукція або послуги, а також організаційно-технічні рішення виробничого, адміністративного, комерційного або іншого характеру, що істотно поліпшують структуру та якість виробництва і (або) соціальної сфери [19, с. 93].

Узагальнюючи розглянуті позиції, можна дійти висновку, що поняття «інновація» інтерпретується переважною більшістю авторів із чотирьох позицій: (1) як система, (2) як зміни, (3) як певний процес, спрямований на досягнення результату та (4) як результат.

Міжнародні стандарти (Fraskati Manual, Oslo Manual) в інноваційній сфері трактують інновацію як кінцевий результат інноваційної діяльності, втілений у формі нового або вдосконаленого продукту або технологічного процесу, що використовується на практиці або в новому підході до соціальних послуг [20, с.19; 21, с.27].

Таким чином, незважаючи на різні підходи до тлумачення терміна «інновація», всі визначення поєднує позиція, згідно з якою інновації пов'язані 3 якісними перетвореннями, спрямованими на створення нового або вдосконалення товару, технології, процесу лише за умови їх комерціалізації.

Аналіз економічної літератури дозволив сформулювати висновок про те, що визначення інновації в обов'язковому порядку повинно:

- характеризуватися кінцевим результатом - мати елементи новизни;

- містити групи об'єктів або процесів, на які може поширюватися;

- відповідати потребам і запитам споживачів;

- $\quad$ мати посилання на досягнення певного ефекту (приносити прибуток іiі розробнику, виробнику, продавцю, а також суспільству в цілому; забезпечувати 
економію витрат, підвищення рівня ефективності, рентабельності виробництва тощо).

Системний аналіз наукового тлумачення сутності економічних категорій «розвиток» та «інновації», критична оцінка цих узагальнюючих понять різними вченими дали змогу визначити авторську його інтерпретацію. Інноваційний розвиток організації означає процес кількісних і якісних перетворень, що спирається на перманентний пошук і впровадження нових способів і сфер реалізації потенціалу підприємства 3 метою набуття конкурентних переваг в умовах глобалізації економіки, спрямованих на задоволення потреб клієнтів, споживачів, партнерів підприємства, галузі, регіону, країни та одержання позитивного (економічного, соціального, екологічного, науково-технічного або іншого) ефекту.

Розглянемо детальніше можливі напрямки інноваційного розвитку морських портів України на підставі узагальнення здобутків та імператив провідних портів світу.

Наразі головним імперативом інноваційного розвитку у світі $є$ цифровізація. Поширенню цифровізації у морських портах сприятимуть Інтернет речей, автоматизація, роботизація, штучний інтелект, безпілотні транспортні засоби та обладнання, технологія блокчейн, розробки у галузі кібербезпеки, 3Dмоделювання та 3D-друк, нанотехнології (наприклад, нанесення нанопокриттів на підводну частину судна 3 метою зменшення тертя та витрат палива та ін.). Впровадження вищезазначених інновацій дозволить крім традиційної обробки суден оптимізувати рух та обслуговування суден і вантажів, прискорювати i автоматизувати процеси завдяки більшій прозорості, зменшувати рівень корупції та кількість помилок i, таким чином, підвищувати ефективність діяльності морських портів.

$1 \%$ контейнерних терміналів світу використовують роботизовані та дистанційно-керовані вантажно-розвантажувальні системи, що підвищує продуктивність та ефективність, а також забезпечує безпеку операцій, покращення їх контролю та узгодженість i призводить до скорочення експлуатаційних витрат терміналів, покращання екології, зміцнення конкурентних переваг порту [22, с.78]. Проте, значні інвестиції, брак кваліфікованих людських ресурсів, стурбованість з боку профспілок щодо скорочення чисельності працівників та необхідності їх перенавчання i забезпечення зайнятості, а також час, необхідний для впровадження інновацій, перешкоджають ширшому впровадженню автоматизації у портах.

Інвестиції у днопоглиблювальні роботи, сучасне потужне підйомнотранспортне обладнання, розширення акваторії порту для заходу та обробки великих суден, штучний інтелект та блокчейн для удосконалення обміну 
інформацією між різними учасниками процесу транспортування, створення сайтів для портових логістичних та виробничих операцій у портовій зоні дозволить збільшити трафік та кількість суднозаходів, розробка і впровадження сучасних засобів для бункерування, а також використання скрапленого природного газу в якості суднового палива, електрифікація, в т.ч. перехід суден та берегове енергопостачання, сприятимуть зменшенню шкідливих викидів у порту та підвищенню ефективності його роботи.

Фахівці зазначають, що клієнти жадають кращого, швидшого, більш інтелектуального порту [22, с.83]. Концепція інтелектуального порту передбачає впровадження низки передових технологій: від штучного інтелекту до хмарних сервісів і технології блокчейн для управління та відстеження руху вантажів, використання яких дозволить портам i вантажовідправникам підвищити ефективність операцій. За прогнозами світових аналітиків в найближчі п'ять років ринок інтелектуальних портових технологій зросте на майже 2 млрд. доларів [23].

Портові оператори Китаю тримають пальму першості щодо автоматизації портів. Так, Shanghai Yangshan Phase IV є найбільшим повністю автоматизованим терміналом у світі. Разом з підвищенням пропускної здатності порту повністю автоматизований термінал дозволяє знизити викиди вуглецю до 10\% [23]. Варто звернути увагу, що з 2016 року він має статус зони вільної торгівлі, що прискорює митні процедури і полегшує перевезення або зберігання вантажів іноземного походження. Такий досвід є корисним для українських морських портів, що дозволило б скерувати частину міжнародних вантажних потоків до держави [23].

China Merchant Port Group, яка управляє 41 портом у Китаї і 25 в інших країнах, разом 3 Alibaba Group i Ant Financial Group планують створити платформу, яка дозволить покупцям i продавцям товарів інтегруватися 3 логістичними компаніями, банками, митницею та ін. для проведення безконтактних цифрових операцій з експорту та імпорту в портах. Така інтеграція разом $з$ використанням технології блокчейн могла б бути цінною і для України: сприяти зменшенню корумпованості та підвищенню привабливості вітчизняних морських портів в очах світових судновласників та судноплавних компаній [23].

Разом з Китаєм планують будувати інтелектуальні порти та впроваджувати технології оптимізації Велика Британія, Німеччина, Канада, Нідерланди та ін.

Так, контейнерний термінал Tilbury в Лондоні використовує мобільний застосунок для системи бронювання транспортних засобів, що дозволяє перевізникам здійснювати замовлення і перевіряти стан контейнерів віддалено, зі смартфонів. Глобальний контейнерний гігант CMA CGM має мобільний додаток, який показує дані щодо перевезень контейнерів та розкладу рейсів [23].

Адміністрація порту Монреаля впровадила веб-додаток Trucking PORTal для 
скорочення рівня забруднення і збільшення продуктивності шляхом оптимізації маршрутів вантажівок і скорочення корок на в'їздах і виїздах у термінали. Інформація, отримана за допомогою Bluetooth, RFID i зчитування номерів транспорту, передається водіям у реальному часі, що дозволяє скоротити час очікування та викиди парникових газів на території порту [24]. У порту Антверпен також впроваджено цифрову 3D-карту порту, яка містить інформацію в режимі реального часу [22, с. 89].

Компанія IBM повідомила, що наразі готується перетворення порту Роттердам на інтелектуальний порт. Вся територія порту протяжністю 42 км, від міста Роттердама до Північного моря буде покрита системою інтернету речей (IoT) та IBM Cloud. Планується відтворити точну цифрову копію поточних операцій за допомогою даних 3 датчиків, встановлених на причалах, якірних причалах, фарватерах, дорогах та ін., які відображатимуть всі ресурси порту Роттердам, відстежувати рух суден, інфраструктуру, погоду, географічні і погодні дані зі 100\% вірогідністю [23]. Варто додати, що для збереження екосистеми порт Роттердам використовує безпечні, рентабельні магнітні якорі - McNetiq, які можна приєднати до сталевої стіни без зварювання [22, с. 87].

Технологія інтелектуальних портів дозволить спростити судноплавну галузь - крім оптимізації і прискорення багатьох портових процесів, вона позитивно позначиться на екології та безпеці суден. Так, система збору гідро- та метеоданих підкаже найкращий час для входу судна в порт або виходу з нього тощо [23].

У порту Антверпен для вимірювання глибин шляхом збирання докладної інформації в хмарі 3 метою гарантування безпечного проходу для транспортування застосовують повністю автоматизоване (працює самостійно, без присутніх на борту) звукове судно Echdrone, яке є одним 3 перших абсолютно нових поколінь роботів [22, с. 88].

У порту Гамбург у 2018 р. проведено випробування підводного дрона iXblue для впровадження системи автоматичного лоцмана. Цікавою $є$ ідея компанії Hyperloop Transportation Tecnologies paзом 3 контейнерним оператором порту Гамбург щодо створення системи перевезення вантажів тунелями, яка дозволить підключити термінал до суднобудівних заводів, розташованих всередині країни, i, таким чином, збільшити обсяг вантажу для обробки [22, с. 94].

Порт Сінгапур розвиває безекіпажний портофлот (буксири, лоцманські катери, швартувальні судна, невеликі пороми) [22, с. 91], а також планує впровадження системи управління безпілотними літальними апаратами для доставки вантажів з берега на судна, що знаходяться на якірній стоянці. Система дозволить знизити витрати до 90\% та усунути ризики доставки іншими шляхами [24]. Наразі виконуються тестові відправлення документації, запасних частин та ін. на судна, які стоять на якорі. 
Нами встановлено, що при розробці та реалізації стратегій інноваційного розвитку виникають проблеми щодо скоординованого, синергетичного впровадження різнопланових заходів з урахуванням їх ресурсного забезпечення. Тому реалізацію стратегії інноваційного розвитку доцільно здійснювати за допомогою збалансованої системи показників (BSC) Р. Каплана і Д. Нортона, тому стратегічні імперативи морського порту також розподілимо на відповідні блоки: фінанси, клієнти, внутрішні бізнес-процеси, навчання i розвиток персоналу (таблиця 3) [25, с. 271].

Таблиия 3

\section{Стратегічні напрями інноваційного розвитку морських портів України}

\begin{tabular}{|c|c|}
\hline Блок & Напрями інновацій \\
\hline Фінанси & $\begin{array}{l}\text { Цифровізація; хмарні технології і технології з використання мобільних додатків; } \\
\text { блокчейн; кібербезпека; штучний інтелект; оптимізація витрат та покращання } \\
\text { фінансового стану }\end{array}$ \\
\hline Клієнти & $\begin{array}{l}\text { Хмарні технології; блокчейн; кібербезпека; штучний інтелект; оперативність } \\
\text { ухвалення управлінських рішень; підвищення якості, швидкості, безпеки та } \\
\text { ефективності послуг }\end{array}$ \\
\hline \multirow{3}{*}{$\begin{array}{l}\text { Внутрішні } \\
\text { бізнес- } \\
\text { процеси }\end{array}$} & Маркетинг \\
\hline & 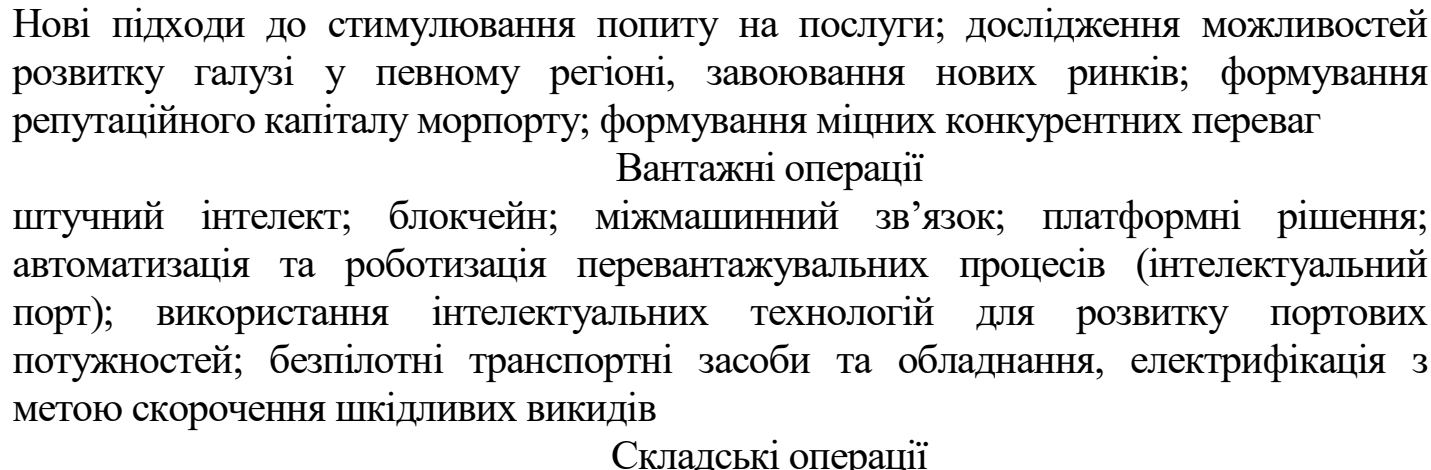 \\
\hline & $\begin{array}{l}\text { методи аналізу великих даних; «смарт» лічильники; єдине відображення } \\
\text { інформації про вантажі, що зберігаються; хмарні технології; блокчейн; } \\
\text { кібербезпека; штучний інтелект; створення сухих портів } \\
\text { Експлуатація об'єктів } \\
\text { «розумні»енергомережі; ресурсозбереження та раціональне споживання ресурсів } \\
\text { (енергоефективний порт) та стимулювання кругової діяльності в порту; аналіз } \\
\text { безпеки; профілактичне технічне обслуговування; нанотехнології; екологічно } \\
\text { безпечні технології, спрямовані на зменшення шкідливих викидів від виробничих } \\
\text { процесів у порту, отримання енергії з альтернативних джерел (зелений порт); } \\
\text { достатня глибина підхідних каналів; інтелектуальні причали відповідної довжини } \\
\text { (щоб судна не шукали місця для паркування, а правильно швартувались); } \\
\text { автономні безпілотні літальні апарати; комплекс наземних транспортних сервісів і } \\
\text { зручний доступ; 3D-карта порту з відображенням поточної ситуації в реальному } \\
\text { часі; електронні повідомлення щодо бункерування, логістичних потоків всередині } \\
\text { порту тощо, спостерігання за ситуацієюу порту і постачальниками послуг з метою } \\
\text { засвідчення безпечності та надійності послуг; безекіпажний портофлот; } \\
\text { використання магнітних якорів; підводні дрони для впровадження системи } \\
\text { автоматичного лоцмана }\end{array}$ \\
\hline $\begin{array}{l}\text { Навчання і } \\
\text { розвиток } \\
\text { персоналу }\end{array}$ & $\begin{array}{l}\text { Мобільність людського капіталу; креативність; комунікативність; розвиток } \\
\text { цифрових компетентностей; перманентне вдосконалення спеціальних знань і } \\
\text { методів роботи }\end{array}$ \\
\hline
\end{tabular}


Проведені автором дослідження щодо впровадження новітніх технологій у діяльність провідних портів світу підтверджують необхідність та нагальність інноваційного розвитку портової галузі України. Безумовно 3 огляду вищезазначених стратегічних векторів видно, що одразу зазначені напрямки впровадити неможливо через брак необхідних ресурсів. Тому для вибору пріоритетних стратегічних імператив для кожного порту доцільно використати метод аналізу ієрархій, який буде розглянуто автором у подальших дослідженнях.

Висновки. Інновації дозволяють забезпечити сталий розвиток підприємства, ознаками якого $\epsilon$ інтелектуалізація виробничої діяльності, екологічність, використання високих технологій тощо. Рушійною силою інноваційного розвитку є зміни у зовнішньому оточенні організації (соціальні, політичні, економічні, демографічні, науково-технічні), що вимагають взаємопов'язаних змін внутрішнього середовища підприємства.

Наразі світ активно працює над створенням інтелектуальних морських портів. Дослідження прикладів інноваційного розвитку провідних портів світу дозволило узагальнити новітні тенденції портової індустрії: цифровізація логістичних потоків та обробки різноманітних даних, роботизація суден та використання дронів, автоматизація процесу управління, збільшення пропускної здатності портів та ін., що сприятиме поліпшенню екології, зменшенню рівня корупції та кількості помилок i, таким чином, підвищенню конкурентоспроможності та ефективності діяльності вітчизняних морських портів.

\section{Лimepamypa:}

1. Інформація про водний транспорт України. Міністерство інфраструктури України : веб-сайт. URL: https://mtu.gov.ua/content/informaciya-pro/ vodniy-transport-ukraini.html (дата звернення 15.08.2021).

2. Ниякий И. Моряки приносят Украине \$3 млрд в год. Они могут потерять работу. ЛIГА.net : новинний портал. URL: https://biz.liga.net/ekonomika/trans port/opinion/moryakiprinosyat-ukraine-3-mlrd-v-god-no-mogut-poteryat-rabotu (дата звернення 15.08.2021).

3. Економічна енциклопедія: в 3 т. / за ред. С.В. Мочерного. Київ : Академія, 2002. Т. 3.952 c.

4. Экономика / под ред. А.С. Булатова. Москва : БЕК, 1997. 816 с.

5. Гуийяр Ф.Ж., Келли Дж.Н. Преобразование организации. Москва : Дело, 2000. 376 с.

6. Афанасьев Н.В., Рогожин В.Д., Рудыка В.И. Управление развитием предприятия : монография. Харьков : ИНЖЕК, 2003. 184 с.

7. Пономаренко О.І., Пономаренко В.О. Системні методи в економіці, менеджменті та бізнесі: навч. посібник. Київ : Либідь, 1995. 240 с.

8. Краснокутська Н.В. Інноваційний менеджмент: навч. посібник. Київ : КНЕУ, 2003. $504 \mathrm{c}$.

9. Антонюк Л.Л., Поручник А.М., Савчук В.С. Інновації: теорія, механізм розробки та комерціалізації : монографія. Київ, КНЕУ, 2003. 394 с. 
10. Портер М. Конкуренция: учеб. пособие : пер. с англ. Москва : Вильямс, 2001. 495 с.

11. Шумпетер Й.А. Теория экономического развития: Исследование предпринимательской прибыли, капитала, кредита, процента и цикла конъюнктуры. Москва : Прогресс, 1982. 456 с.

12. Crumball Clive. Managing of Innovations. Cambridge: Woodhead-Janekner, 1998. 150 p.

13. Яковец Ю.В. Ускорение научно-технического прогресса: теория и экономический механизм. Москва : Экономика, 1988. 342 с.

14. Твисс Б. Управление научно-техническими нововведениями. Москва : Экономика, 1989. $271 \mathrm{c}$.

15. Санто Б. Инновация как средство экономического развития. Москва : Прогресс, 1990. $291 \mathrm{c}$.

16. Лапко О. О. Інноваційна діяльність в системі державного регулювання. Київ : ІЕП НАНУ, 1999. - $254 \mathrm{c}$.

17. Riggs H.T. Managing High Technology Companies Belmont. New York, 1983. 333 p.

18. Hippel V.L. U.S. high technology trade and competitiveness. Staffreport/U.S. Department of Commerce. 1985. 112 p.

19. Про пріоритетні напрями інноваційної діяльності в Україні Закон України від 05.12.2012 № 5460-VI / Верховна Рада України. URL: https://zakon.rada.gov.ua/ laws/show/4015\#Text (дата звернення 05.08.2021).

20. Руководство Фраскати, издание на русском языке (Organization for Economic Cooperation and Development (OECD), Москва, Париж и Центр исследований и статистики науки (ЦИСН), 1995. 381 с.

21. OECD Proposed Quibelines for Collecting and Interpreting Technogical Innovation Data. Oslo manual. OECD. Paris, 1992. 103 p.

22. Аляб'єва О.М. Організаційно-економічний механізм інноваційного розвитку морських портів : дис. ... канд.. екон. наук: 08.00.04. Київ, 2020. 209 с.

23. Кумеков Р. Мир готовится к внедрению интеллектуальных портов. Судоходство : веб-сайт. URL: https://sudohodstvo.org/mir-gotovitsya-k-vnedreniyu-intellektualnyh-portov/ (дата звернення 18.08.2021).

24. Дроны в порту Сингапур. Seanews : веб-сайт. URL: https://seanews.ru/2018/08/09/dronyv-portu-singapur/ (дата звернення 17.08.2021)

25. Стовба Т.А. Методичні аспекти оцінки та формування інноваційного потенціалу морського порту. Наукові перспективи. 2021. №7 (13). С. 267-279.

\section{References:}

1. Informatsiya pro vodnyy transport Ukrayiny [Ministerstvo infrastruktury Ukrayiny]. (n.d.). mtu.gov.ua. Retrieved from https://mtu.gov.ua/content/informaciya-pro-vodniy-transport-ukraini.html [in Russian].

2. Niyakiy I. Moryaki prinosyat Ukraine $\$ 3 \mathrm{mlrd} v$ god. Oni mogut poteryat' rabotu [Sailors bring Ukraine $\$ 3$ billion a year. They may lose their jobs]. (n.d.). biz.liga.net. Retrieved from https://biz.liga.net/ekonomika/transport/opinion/moryaki-prinosyat-ukraine-3-mlrd-v-god-nomogut-poteryat-rabotu [in Russian].

3. Mochernyy, S.V. (Eds.). (2002). Ekonomichna entsyklopediya [Economic Encyclopedia]. (Vols. 1-3) Kyyiv: Akademiya, 2002 [in Ukrainian].

4. Bulatov, A.S. (Eds.). (1997). Ekonomika [Economics]. Moskva : BEK [in Russian]. 
5. Guiyyar, F.ZH. \& Kelli, Dzh.N. (2000). Preobrazovaniye organizatsii [Organization transformation]. Moskva: Delo [in Russian].

6. Afanas'yev N.V., Rogozhin V.D., \& Rudyka V.I. (2003). Upravleniye razvitiyem predpriyatiya [Enterprise development management]. Khar'kov: INZHEK [in Russian].

7. Ponomarenko, O.I., \& Ponomarenko V.O. (1995). Systemni metody $v$ ekonomitsi, menedzhmenti ta biznesi [System methods in economics, management and business]. Kyyiv: Lybid' [in Ukrainian].

8. Krasnokuts'ka, N.V. (2003). Innovatsiynyy menedzhment [Innovation management]. Kyyiv: KNEU [in Ukrainian].

9. Antonyuk, L.L., Poruchnyk, A.M., \& Savchuk V.S. (2003). Innovatsiyi: teoriya, mekhanizm rozrobky ta komertsializatsiyi [Innovations: theory, mechanism of development and commercialization]. Kyyiv: KNEU [in Ukrainian].

10.Porter, M. (2001). Konkurentsiya [Competition]. Moskva: Vil'yams [in Russian].

11.Shumpeter, Y.A. (1982). Teoriya ekonomicheskogo razvitiya: Issledovaniye predprinimatel'skoy pribyli, kapitala, kredita, protsenta i tsikla kon"yunktury [Economic Development Theory: A Study of Entrepreneurial Profit, Capital, Credit, Interest, and the Business Cycle]. Moskva: Progress [in Russian].

12.Crumball, C. (1998). Managing of Innovations. Cambridge: Woodhead -Janekner [in English].

13.Yakovets, YU.V. (1988). Uskoreniye nauchno-tekhnicheskogo progressa: teoriya i ekonomicheskiy mekhanízm [Acceleration of scientific and technological progress: theory and economic mechanism]. Moskva: Ekonomika [in Russian].

14.Tviss, B. (1989). Upravleniye nauchno-tekhnicheskimi novovvedeniyami [Management of scientific and technical innovations]. Moskva: Ekonomika [in Russian].

15. Santo, B. (1990). Innovatsiya kak sredstvo ekonomicheskogo razvitiya [Innovation as a means of economic development]. Moskva: Progress [in Russian].

16. Lapko, O.O. (1999). Innovatsiyna diyal'nist' v systemi derzhavnoho rehulyuvannya [Innovative activity in the system of state regulation]. Kyyiv: IEP NASU [in Ukrainian].

17. Riggs, H.T. (1983). Managing High Technology Companies Belmont. New York [in English].

18. Hippel, V.L. (1985). U.S. high technology trade and competitiveness. Staffreport /U.S. Department of Commerce [in English].

19. Zakon Ukrayiny «Pro priorytetni napryamy innovatsiynoyi diyal'nosti v Ukrayini» [The Law of Ukraine «On priority areas of innovation in Ukraine»] (n.d.). zakon.rada.gov.ua. Retrieved from https://zakon.rada.gov.ua/laws/show/40-15\#Text [in Ukrainian].

20. Rukovodstvo Fraskati, izdaniye na russkom yazyke (Organization for Economic Cooperation and Development (OECD) [Frascati Manual, Russian edition (Organization for Economic Cooperation and Development (OECD)]. (1995). Moskva, Parizh: Tsentr issledovaniy i statistiki nauki (TSISN) [in Russian].

21. OECD Proposed Quibelines for Collecting and Interpreting Technogical Innovation Data. Oslo manual. (1992). Paris, OECD [in English].

22. Alyab'yeva, O.M. (2020). Orhanizatsiyno-ekonomichnyy mekhanizm innovatsiynoho rozvytku mors'kykh portiv [Organizational and economic mechanism of innovative development of seaports]. Candidate's thesis. Kyyiv: Derzhavnyy universytet infrastruktury ta tekhnolohiy [in Ukrainian]. 
23. Kumekov, R. (2020). Mir gotovitsya k vnedreniyu intellektual'nykh portov [The world is preparing for the introduction of smart ports]. (n.d.). sudohodstvo.org. Retrieved from https://sudohodstvo.org/mir-gotovitsya-k-vnedreniyu-intellektualnyh-portov/ [in Russian].

24. Drony v portu Singapur [Drones in the port of Singapore]. (n.d.). seanews.ru. Retrieved from https://seanews.ru/2018/08/09/drony-v-portu-singapur/ [in Russian].

25. Stovba, T.A. (2021). Metodychni aspekty otsinky ta formuvannya innovatsiynoho potentsialu mors'koho portu [Methodological aspects of assessment and formation of seaport innovative potential]. Naukovi perspektyvy - Scientific perspectives, 7(13), 267-279 [in Ukrainian]. 